\title{
SESTON DYNAMICS AND BIVALVE FEEDING IN THE BAY OF MARENNES-OLÉRON (FRANCE) *
}

\author{
WOUTER ZURBURG ${ }^{1}$, AAD SMAAL $^{2}$, MAURICE HÉRAL ${ }^{3}$ and NORBERT DANKERS 4
}

KEYWORDS: seston load; seston quality; oyster; mussel; feeding; chlorophyll; microphytobenthos.

\begin{abstract}
Within the framework of an investigation into the carrying capacity of the Bay of Marennes-0léron (France) for bivalve culture, the in situ uptake of suspended particulate material by oysters (Crassostrea gigas) and mussels (Mytilus edulis) was determined in experiments with benthic ecosystem tunnels. Very high fluctuations in seston quantity and quality were observed within and between tidal cycles. The percentage of organic carbon was inversely related to seston quantity at low concentrations. Organic carbon was diluted by resuspension of material rich in inorganic matter. At high seston concentrations a constant level of about $2 \%$ organic carbon was found. The $\mathrm{C} / \mathrm{N}$ ratio was relatively constant throughout the seasons and fairly low (6.5 to 8.4). Owing to the presence of bivalves large fluxes of suspended particulate material were observed in the in situ measurements. Selective retention of organic carbon or nitrogen could not be demonstrated. Clearance rates based on chlorophyll uptake were within a normal range compared to other studies. A large contribution to the food of the bivalves seemed to be formed by resuspended microphytobenthos. Judged by the low $\mathrm{C} / \mathrm{N}$ ratio, the food was of good quality. Although its quantity was variable by dilution, it may support largely the carrying capacity of the Bay of Marennes-Oléron for the cultivation of bivalves.
\end{abstract}

\section{INTRODUCTION}

In the Bay of Marennes-Oléron (France) the water column is characterized by high turbidity levels that are influenced by season, lunar cycles (spring, neap tides), bathymetry, currents and wind (HÉRAL et al., 1983; PROU, 1991). High seston loads restrict primary production through light limitation, and moreover affect food availability to suspension feeding organisms, such as bivalves, by its dilution.

The total biomass of oysters (Crassostrea gigas) and mussels (Mytilus edulis) which are extensively cultivated in the Bay of Marennes-Oléron, varies around 100,000 tonnes (fresh weight) (BACHER, 1989). In such dense communities, bivalve species are known for their high filtration capacities and the enhancernent of sedimentation processes (SORNIN et al., 1983, 1986; SMAAL et al., 1986; KAUTSKY and EVANS, 1987). SMAAL and PRINS (1993) estimated that the total water volume of the Bay of Marennes-Oléron could be filtered in $3 \mathrm{~d}$ by the bivalves present in this area. The quality of the filtered material is therefore of utmost importance for the growth of these organisms.

As part of an investigation into the trophic capacity of the Bay of Marennes-Oléron, the in situ uptake of suspended particulate material by oysters (Crassostrea gigas) and mussels (Mytilus edulis) was studied during various seasons, by applying the Benthic Ecosystem Tunnel developed by DAME

*Communication no. 687 of the Netherlands Institute of Ecology, Centre for Estuarine and Coastal Ecology, Yerseke, the Netherlands. 


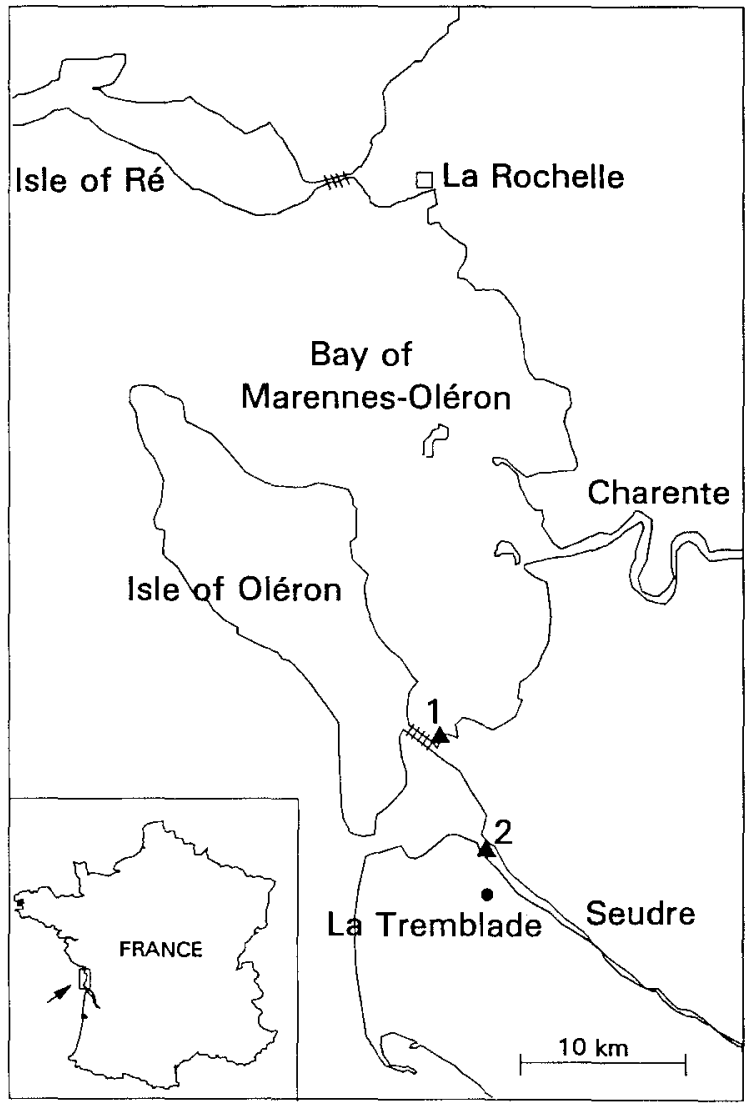

Fig. 1. Location of the experimental sites Le Chapus (1) and Seudre (2) in the Bay of Marennes-Oleron (France).

et al. (1984) and used earlier over mussel and oyster beds in The Netherlands by DAME and DANKERS (1988), DAME et al. (1991) and PRINS and SMAAL $(1990,1994)$. Part of the results on the uptake and release of material by oysters in the Bay of Marennes-Oléron was presented earlier (ZURBURG et al., 1994). In the present paper, the food uptake by oysters and mussels is discussed in relation to the variations in seston quantity and quality in the overlying water.

\section{MATERIALS AND METHODS}

Uptake of suspended materials was determined in situ with two Benthic Ecosystem Tunnels, as described by ZURBURG et al. (1994). Both tunnels were used in parallel over oysters (Crassostrea gigas) or mussels (Mytilus edulis) or over empty oyster shells (control). The tunnels are made of Plexiglass plates, joined together by neoprene strips. The total length between sampling points appro- ximates $10 \mathrm{~m}$, the width $0.80 \mathrm{~m}$ and the crosssectional area $0.23 \mathrm{~m}^{2}$. About $8 \mathrm{~m}^{2}$ of bottom area with or without animals were covered.

Measurements were carried out in the Bay of Marennes-Oléron (France) at Le Chapus in spring (May 1991 and 1992), autumn (October 1991) and winter (February 1992) and in the Seudre in spring (June 1992) and autumn (October 1992) (Fig. 1). Experiments were performed during 32 different tidal cycles.

\section{Sampling procedure}

The tunnels were submersed for 8-10 h during each tidal cycle at spring tide or up to about $11 \mathrm{~h}$ at neap tide. From a small boat lying between the tunnels, water samples of 1 I were taken at the inflow and the outflow with battery driven pumps every 20-30 min during the period of submersion. Samples were analyzed for seston, particulate organic carbon (POC) and nitrogen (PON) and chlorophyll-a. Details of the analytical methods have been described by PRINS and SMAAL (1990) and DAME et al. (1991).

After each experiment samples of the oysters and mussels were taken from three different locations within the tunnel and dried for at least $48 \mathrm{~h}$ at $70^{\circ} \mathrm{C}$. Subsequently the samples were dried for $4 \mathrm{~h}$ at $520^{\circ} \mathrm{C}$ for the determination of the ash-free dry weight (AFDW). The biomass was between 129 and $236 \mathrm{~g}$ AFDW m-2 (174-312 individuals $\mathrm{m}^{-2}$ ) for oysters and between 436 and $1101 \mathrm{~g}$ AFDW $\mathrm{m}^{-2}$ (1500-7900 individuals $\left.\mathrm{m}^{-2}\right)$ for mussels.

\section{Calculation of fluxes and statistical treatment of the results}

Water flow through the tunnels was calculated from current velocity data continuously recorded by induction flow meters (Marsh McBirney $201 \mathrm{M}$ or NSW Meerestechnik) placed in the centre of the tunnels. Earlier calibration studies were used to correlate the current measured at a single point to water flow (DAME et al., 1984; PRINS and SMAAL, 1990). The fluxes of material were calculated from water flow times and the difference between the inflow and outflow concentrations. Fluxes of control and experimental tunnels were compared by the Mann-Whitney U test.

Fluxes occurring at current speeds lower than $2 \mathrm{~cm} \mathrm{~s}^{-1}$ were excluded from calculations as vertical mixing of the water within the tunnel probably was not complete (PRINS et al., unpubl. data).

The residence time of the water within the tunnels can be calculated to be less than $8 \mathrm{~min}$ at current speeds higher than $2 \mathrm{~cm} \mathrm{~s}^{-1}$. 


\section{Clearance rates}

Clearance rates (CR) based on chlorophyll were calculated according to

$$
C R_{\text {bed }}=\frac{Q \ln \left(C_{\text {chl in }} / C_{\text {chl out }}\right)}{A}
$$

where $\mathrm{CR}_{\text {bed }}=$ clearance rate of the mussel or oyster bed $\left(\mathrm{m}^{3} \mathrm{~m}^{-2} \mathrm{~h}^{-1}\right), Q$ = water flux through the tunnel $\left(\mathrm{m}^{3} \mathrm{~h}^{-1}\right), \mathrm{C}_{\mathrm{chl}}$ in $=$ concentration of chlorophyll in the sea water at the entrance of the tunnel $\left(\mu \mathrm{g} \mathrm{I}^{-1}\right), \mathrm{C}_{\mathrm{chl}}$ out $=$ concentration of chlorophyll at the outlet of the tunnel $\left(\mu \mathrm{g} \mathrm{I}^{-1}\right)$ and $A=$ surface area of the mussel or oyster bed between the sampling points $\left(\mathrm{m}^{2}\right)$. Bed clearance rates depend on the individual clearance rates and the density of the oysters or mussels. Clearance rate as a function of body size is expressed by $\mathrm{CR}_{\mathrm{i}}$ $=\mathrm{aW}$ b with $\mathrm{a}=$ clearance rate of $\mathrm{a}$ standard animal of $1 \mathrm{~g}$ ash-free dry weight and $W_{i}=$ weight of individual animal, $b=$ weight-exponent. From $\mathrm{CR}_{\text {bed }}=\mathrm{a} \Sigma\left(\mathrm{n}_{\mathrm{i}}, \mathrm{W}_{\mathrm{i}}^{\mathrm{b}}\right)$ with $\mathrm{n}_{\mathrm{i}}=$ number of animals of sizeclass $i$, the clearance rate of a standard animal (a) can be calculated.

The value of $b$ taken was 0.67 for mussels (JONES et al., 1992). For oysters the value of 0.439 was taken as found by FIALA-MEDIONI et al. (1984) and by S. BOUgRIER (pers. comm.) for the population of Crassostrea gigas under study. Corrections were made for chlorophyll uptake or release in the control tunnel. Computing averages over tidal cycles, negative values found for clearance rates were considered to be zero.

\section{RESULTS}

\section{Characteristics of seston}

From the water samples taken at the entrance of the benthic ecosystem tunnels some characteristics of the water column become evident. The variation in seston quantities in the water column of the Bay of Marennes-Oléron is presented in Table 1 for the two locations used in our experiments. The concentrations varied from 7 to $>300 \mathrm{mg} \mathrm{l}^{-1}$. Particulate organic carbon (POC) concentrations increased linearly with seston concentrations as shown in Fig. 2 for the October 1991 and 1992 experiments. The percentage of organic carbon (Fig. 3 ) remained constant at high seston concentrations (around $2 \%$ ), but was inversely related to seston at low concentrations. In the other experimental periods similar patterns were observed (not shown). Chlorophyll concentrations varied largely over the
Table 1. Mean concentrations of seston ( $m \mathrm{I}^{-1}$ ), chlorophyll ( $\mu \mathrm{g}$ $1^{-1}$ ) and $\mathrm{C} / \mathrm{N}$ ratios in the water entering the tunnels at two locations in the Bay of Marennes-Oléron during six experimental periods. Between brackets: minimum and maximum values. $n$ is number of tidal cycles in each period.

\begin{tabular}{lrlrl}
\hline & $n$ & Seston & Chlorophyll & \multicolumn{1}{l}{ C/N } \\
LE CHAPUS & & & & \\
May 1991 & 2 & $110(28 / 246)$ & $5.6(2.5 / 19.2)$ & $8.14(5.30 / 17.25)$ \\
Oct 1991 & 8 & $114(23 / 331)$ & $2.1(0.3 / 5.6)$ & $8.35(4.01 / 13.25)$ \\
Feb 1992 & 6 & $40(10 / 332)$ & $0.2(0.1 / 1.0)$ & $6.96(3.69 / 13.91)$ \\
May 1992 & 6 & $62(26 / 146)$ & $7.3(1.5 / 14.3)$ & $6.50(3.35 / 9.60)$ \\
SEUDRE & & & & \\
Jun 1992 & 4 & $19(7 / 38)$ & $2.4(0.9 / 4.5)$ & $7.18(4.09 / 14.86)$ \\
OCt 1992 & 8 & $43(8 / 201)$ & $1.5(0.3 / 15.9)$ & $8.35(4.69 / 14.78)$ \\
\hline
\end{tabular}
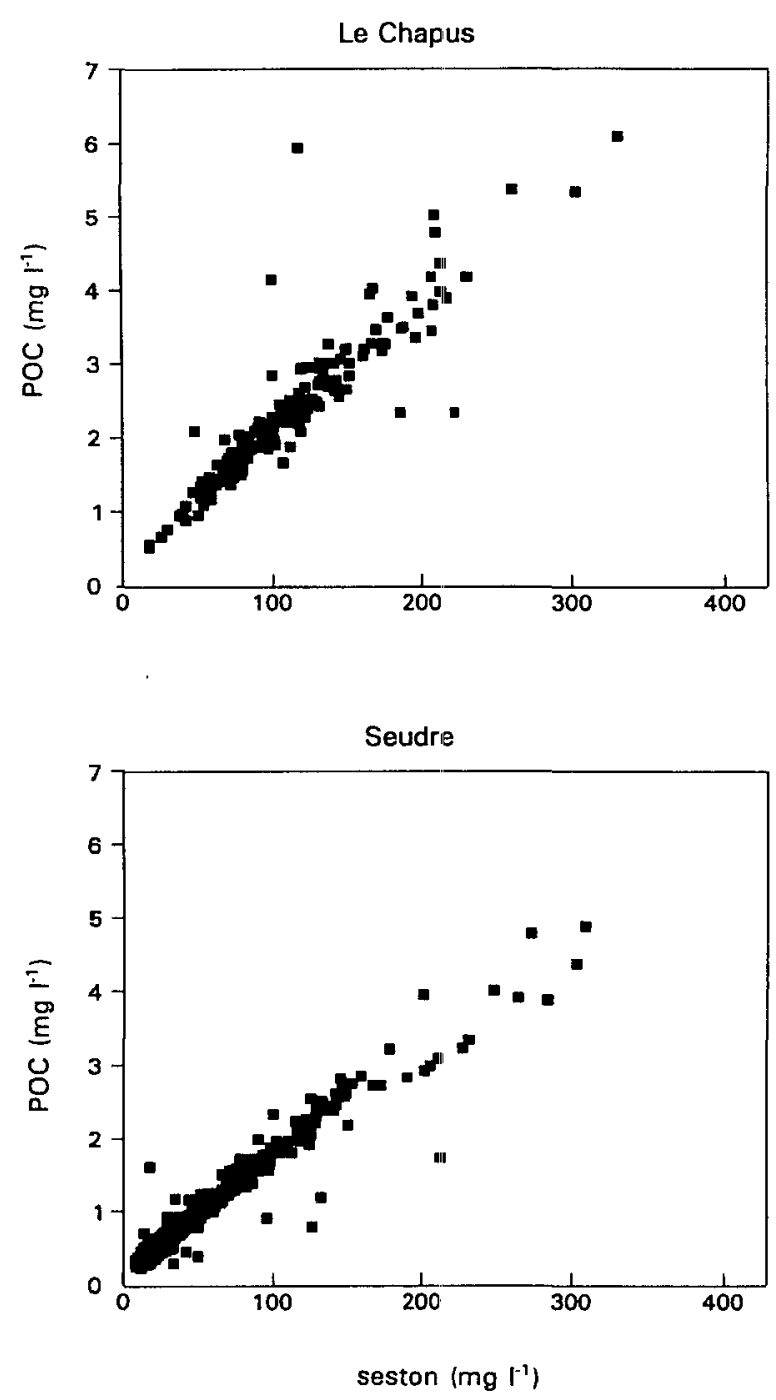

Fig. 2. Relation between POC concentrations (mg $\left.\right|^{-1}$ ) and seston concentrations $\left(\mathrm{mg}^{-1}\right.$ ) at Le Chapus (0ctober 1991, 8 tidal cycles) and in the Seudre (October 1992, 8 tidal cycles). 
Table 2. Fluxes of seston, POC, PON $\left(\mathrm{g} \mathrm{m}^{-2} \mathrm{~h}^{-1}\right)$ and chlorophyll-a $\left(\mathrm{mg} \mathrm{m}^{-2} \mathrm{~h}^{-1}\right)$ in experimental (oyster or mussel) and control tunnels (mean over one tidal cycle, minimum and maximum values). $-=$ release, no sign $=$ uptake. $n$ is number of samples taken during one tidal cycle. Significant differences between experimental and control tunnels are indicated: * $p<0.05,{ }^{* *} p<0.01,{ }^{* *}$ " $p<0.001$ (Mann-Whitney U test)

\begin{tabular}{|c|c|c|c|c|c|c|}
\hline OYSTERS & & $n$ & Seston & POC & PON & Chlorophyll \\
\hline \multicolumn{7}{|l|}{ Le Chapus } \\
\hline \multirow[t]{2}{*}{0 ct 8,1991} & Oysters & 11 & $116(-414 / 279) *$ & $2.2(-6.9 / 5.3) * *$ & $0.37(-1.04 / 0.92)^{\star *}$ & $3.8(-2.3 / 17.0)$ \\
\hline & Control & 11 & $56(-34 / 177)$ & $0.6(-2.9 / 2.4)$ & $0.11(-0.12 / 0.31)$ & $1.1(-2.9 / 9.1)$ \\
\hline \multirow[t]{2}{*}{$\operatorname{Oct} 9,1991$} & Oysters & 12 & $140(-91 / 379)^{* *}$ & $2.0(-2.9 / 7.1) *$ & $0.32(-0.11 / 0.95)^{*}$ & $1.9(-2.4 / 5.6)^{\star}$ \\
\hline & Control & 12 & $18(-137 / 154)$ & $0.2(-3.0 / 3.4)$ & $0.05(-0.48 / 0.50)$ & $0.6(-0.3 / 1.8)$ \\
\hline \multirow{2}{*}{$\begin{array}{l}\text { May 19, } 1992 \\
\text { (night) }\end{array}$} & Oysters & 14 & $97(-8 / 232)$ & $1.0(-1.4 / 3.9)$ & $0.21(-0.92 / 0.97)$ & $14.8(3.1 / 27.7)^{\star \star \star}$ \\
\hline & Control & 14 & $87(-11 / 215)$ & $0.7(-0.4 / 2.9)$ & $0.21(-0.13 / 1.09)$ & $3.2(-3.7 / 15.6)$ \\
\hline \multirow[t]{2}{*}{ May 20, 1992} & Oysters & 15 & $40(-3 / 139)$ & $0.2(-1.2 / 2.1)$ & $-0.07(-1.07 / 0.53)^{*}$ & $4.8(-23.2 / 18.0)^{\star *}$ \\
\hline & Control & 13 & $57(0 / 145)$ & $0.7(-0.2 / 2.3)$ & $0.34(-0.22 / 1.12)$ & $0.4(-16.6 / 7.5)$ \\
\hline \multicolumn{7}{|l|}{ Seudre } \\
\hline \multirow{2}{*}{ Oct 13,1992} & Oysters & 14 & $24(-14 / 87)^{* *}$ & $0.3(-0.4 / 1.4) *$ & $0.11(-0.11 / 0.79)^{*}$ & $0.6(-1.8 / 7.1)$ \\
\hline & Control & 14 & $-30(-340 / 17)$ & $-0.1(-1.2 / 0.4)$ & $-0.04(-0.14 / 0.11)$ & $0.1(-0.7 / 1.1)$ \\
\hline \multicolumn{7}{|l|}{ MUSSELS } \\
\hline \multicolumn{7}{|l|}{ Le Chapus } \\
\hline \multirow[t]{2}{*}{ May 18,1992} & Mussels & 15 & $150(-202 / 820)$ & $0.8(-7.5 / 4.3)$ & $1.14(-0.13 / 7.62) *$ & $10.6(-69.3 / 33.7)^{* *}$ \\
\hline & Control & 15 & $60(-125 / 445)$ & $0.9(-3.7 / 6.3)$ & $-0.01(-2.11 / 1.48)$ & $4.4(-5.1 / 15.6)$ \\
\hline \multirow{2}{*}{$\begin{array}{l}\text { May 19, } 1992 \\
\text { (day) }\end{array}$} & Mussels & 15 & $135(-244 / 360) *$ & $3.0(-3.3 / 8.6)^{\star \star}$ & $0.52(-1.48 / 5.25)$ & $9.7(-22.4 / 23.1)^{* * *}$ \\
\hline & Control & 15 & $82(-9 / 182)$ & $1.5(-0.8 / 3.3)$ & $0.05(-1.08 / 1.41)$ & $1.0(-6.3 / 9.3)$ \\
\hline \multicolumn{7}{|l|}{ Seudre } \\
\hline \multirow[t]{2}{*}{ Oct 26,1992} & Mussels & 16 & $236(-131 / 537)^{* \star *}$ & $3.5(-2.7 / 11.6) *$ & $0.60(-0.41 / 2.00) *$ & $3.6(-3.6 / 12.9)$ \\
\hline & Control & 15 & $11(-142 / 148)$ & $0.3(-2.7 / 3.1)$ & $0.02(-0.90 / 0.49)$ & $1.3(-1.8 / 10.4)$ \\
\hline
\end{tabular}
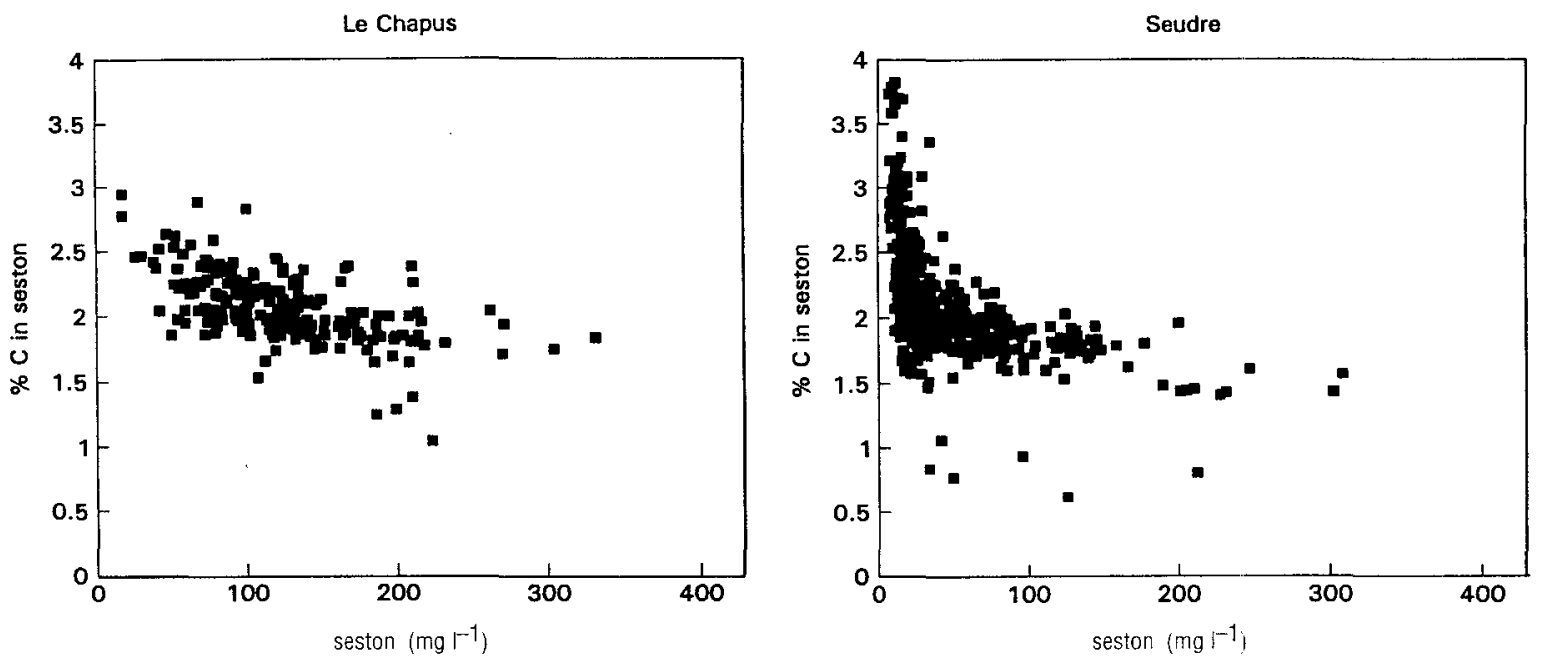

Fig. 3. Fraction of organic carbon (\%) in total seston plotted against seston concentrations (mg $\left.\right|^{-1}$ ) at Le Chapus (October 1991) and in the Seudre (October 1992).

seasons (Table 1). In spring (May), phytoplankton blooms occurred resulting in high maximum values which occurred also in October 1992. In winter (February), concentrations were very low.

The C/N ratio (POC/PON) in the suspended particulate matter was fairly constant during the year with a relatively low mean between 6.5 and 8.4 (Table 1).

\section{Uptake of suspended particulate material}

In the experiments with the Benthic Ecosystem Tunnels uptake of suspended particulate 
material by oysters or mussels was demonstrated In Table 2 fluxes of seston, POC, PON and chlorophyll are given for several experiments. In control experiments with oyster shells also fluxes were observed due to sedimentation or, if negative, by resuspension of particulate material. A general pattern of uptake of material was observed which was enhanced by the presence of oysters or mussels. Chlorophyll uptake was evident in all the presented experiments, although not statistically significant in three cases. Based on the chlorophyll uptake (Table 2), clearance rates were calculated for the oysters and mussels in the May 1992 experiment which are shown in Table 3.

\section{DISCUSSION}

The variation in seston concentrations between 7 and more than $300 \mathrm{mg} \mathrm{I}^{-1}$ (Table 1) has been found in other investigations on the Bay of Marennes-Oléron (HÉRAL et al., 1983; DESLOUS-PAOLI and HÉRAL, 1984; PROU, 1991). An inverse relation-
Table 3. Mean, minimum and maximum clearance rates (in $\mathrm{h} \mathrm{h}^{-1}$ per standard animal of $1 \mathrm{~g}$ AFDW) over one tidal cycle of mussels and oysters based on chlorophyll uptake.

\begin{tabular}{lll}
\hline & Date & $\begin{array}{l}\text { Clearance rate } \\
\text { mean }(\mathrm{min} / \mathrm{max})\end{array}$ \\
Mussels & May 181992 & $2.47(0 / 4.77)$ \\
& May 191992 & $2.36(0 / 5.22)$ \\
Oysters & May 191992 & $7.66(0 / 18.76)$ \\
& May 201992 & $5.50(0 / 16.78)$ \\
\hline
\end{tabular}

ship between the percentage of carbon and seston concentrations (Fig. 3) has been reported earlier by RAZET et al. (1990) and BARILLÉ and PROU (pers. comm.) for the Bay of Marennes-Oléron, but also for other areas, e.g. the Mersey estuary (UK) (PRESTON and PRODDUTURU, 1992). Organic material is diluted by resuspended sediments which consist for about $98 \%$ of inorganic matter. The origin of this material may be variable. Local action of currents could cause resuspension, but the material could be transported also from other parts of the bay after wind-induced resuspension on the tidal front.
Feb 5, 1992

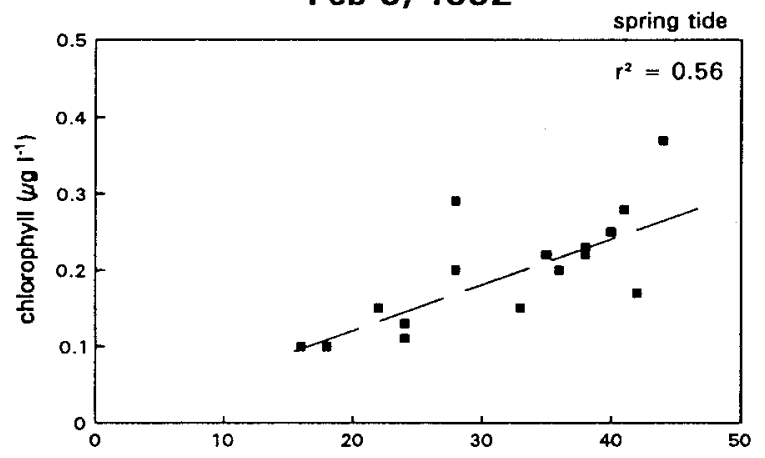

Feb 11, 1992

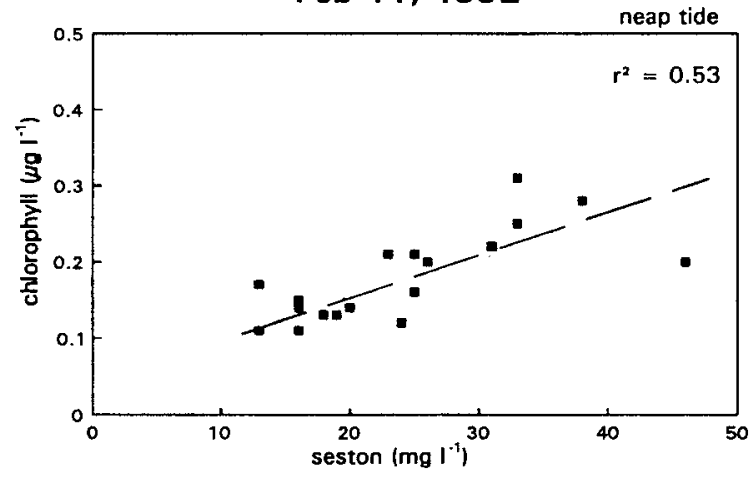

May 19, 1992

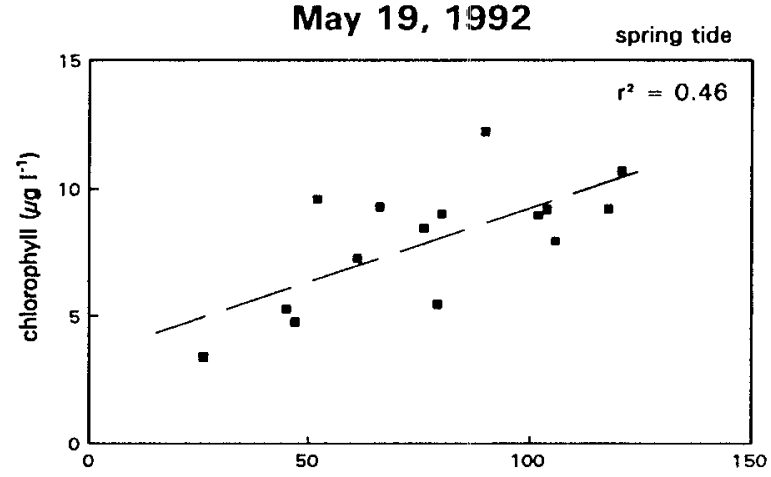

May 28, 1992

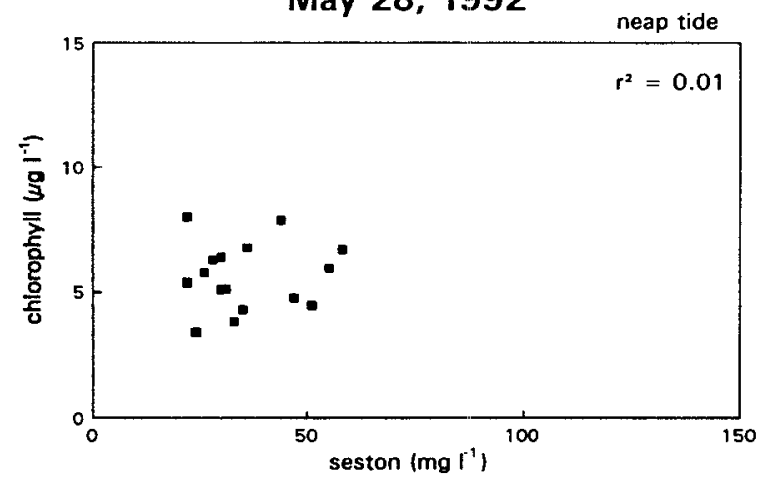

Fig. 4. Relation between chlorophyll concentrations $\left(\mu \mathrm{g}^{-1}\right)$ and seston concentrations ( $\left.\mathrm{mg} \mathrm{I}^{-1}\right)$ at Le Chapus in February and May 1992 during spring tide and neap tide. 
Resuspension processes may also be involved in the origin of chlorophyll in the water column. In winter chlorophyll concentrations were very low (Table 1). At this time pelagic phytoplankton is supposed to be absent. Resuspension of microphytobenthos could then explain the amount of chlorophyll found in the water column. To investigate further the origin of chlorophyll, concentrations of this pigment were plotted against seston concentrations (Fig. 4). In February both at spring and neap tide, a linear relationship between chlorophyll and seston concentrations was found. In May this was only observed at spring tide.

In the experimental area, at neap tides current velocities are usually much lower than at spring tides (PROU, 1991). So at neaps, resuspension of sediment is much less important (sedimentation of particles is dominant), which is evident from the lower seston concentrations at neap tide in May. Here chlorophyll originated from pelagic phytoplankton, whereas at spring tide a mixture from resuspended microphytobenthos and pelagic phytoplankton was present. In May 1990 Prou (1991) demonstrated that at spring tide benthic species formed about $50 \%$ of the diatoms in the water column, whereas at neap tide only about $10 \%$ could be found.

It was calculated that in winter (February), resuspended microphytobenthos may account for all the chlorophyll in the water column. Assuming that microphytobenthos is present in the top centimetre of the sediment only, a bottom chlorophyll concentration of $100 \mathrm{mg} \mathrm{m}^{-2}$ (data from IFREMER) or $10 \mu \mathrm{g} \mathrm{cm}^{-2}$ is equivalent to $10 \mu \mathrm{g}$ $\mathrm{cm}^{-3}$. With a sediment density of $1.8 \mathrm{~g} \mathrm{~cm}^{-3}$ this gives $10 / 1.8=5.5 \mu \mathrm{g}$ chlorophyll per $\mathrm{g}$ of sediment. This value is in good agreement with that of $6.25 \mu \mathrm{g}$ chlorophyll $\mathrm{g}^{-1}$ seston derived from Fig. 4 (February, spring tide, $0.25 \mu \mathrm{g}$ chlorophyll in 40 $\mathrm{mg}$ seston). It is concluded that resuspension of the top layer of the sediment can explain the amount of chlorophyll in the water column in winter.

The relatively low $\mathrm{C} / \mathrm{N}$ ratio found during all experimental periods is similar to that of marine phytoplankton (FENCHEL and JøRGENSEN, 1976), which implies that the organic matter consists mainly of pelagic plankton or/and resuspended microphytobenthos. Consequently, the feeding quality of the (re)suspended particulate material is high. The quantity, however, is relatively low by dilution with inorganic material.

The fluxes of suspended particulate material caused by oysters or mussels (Table 2) imply that sedimentation is greatly enhanced. A flux of $100 \mathrm{~g}$ $\mathrm{m}^{-2} \mathrm{~h}^{-1}$ results in deposition of a layer of about 0.5 $\mathrm{cm}$ on the bottom during one tidal cycle.

Bivalves, in general, are capable of selective retention and ingestion of material from offered food (KIØRBOE and MøHLENBERG, 1981; NEWELL and JORDAN, 1983). From our results no selective retention within the tunnels can be deduced. The POC fluxes did not account for more than $2 \%$ of the seston fluxes (Table 2), the same percentage as found for organic carbon in seston (Fig. 3). In other areas of Europe, selective retention could be demonstrated in situ (SMAAL and PFINS, 1993), but seston concentrations in the water column were generally much lower (around $20 \mathrm{mg} \mathrm{I}^{-1}$ ) than in the Bay of Marennes-Oléron. RAZET et al. (1990) could not find sorting out of organic carbon by the oyster Crassostrea gigas when seston concentrations were over $40 \mathrm{mg} \mathrm{l}^{-1}$. As our experiments were performed mostly at high seston loads (Table 1), our findings confirm those of RAZET et al. Similarly, no selective retention in situ of nitrogen over carbon nor of chlorophyll could be demonstrated.

The seston concentrations found during our experiments were all higher than the threshold concentration for pseudofaeces formation being around $5 \mathrm{mg} \mathrm{l}^{-1}$ for the mussel (BAYNE and NEWELL, 1983 ) and $4.6 \mathrm{mg} \mathrm{l}^{-1}$ for the oyster (DESLOUS-PAOLI et al., 1992). Therefore, large amounts of pseudofaeces must have been formed by the bivalves in the tunnel experiments. From the limited nutrient release in the benthic ecosystem tunnel experiments (ZURBURG et al, 1994) we conclude that the biodeposits formed by the bivalves were resuspended and lost to the environment.

Filtration of suspended particulate material by the bivalves concomitant with processes of sedimentation and resuspension, however, leads to very variable fluxes during one tidal cycle (Table 2). Selective retention of one component over anothe may have been masked by this high variability.

The clearance rates calculated for oysters and mussels in May 1992 (Table 3) of 5-7 and $2.5 \mathrm{I} \mathrm{h}^{-1}$ per standard animal, respectively, fall within the range found for these species by DESLOUS-PAOLI et al. (1987) and BAYNE (1993). The weight-exponent $b$ we used for the oyster $(0.439)$, is lower than the theoretical value of 0.67 for bivalves (JONES et al., 1992) or the value of 0.72 for Crassostrea virginica (RIISGARRD, 1988), but is based on experiments with the same population of Crassostrea gigas (BOUGRIER, personal communication). For the mean size of animals used (0.75-0.80 g AFDW), an exponent of 0.7 would give clearance rates that are only 10-15\% higher than listed in Table 3. 
Compared to laboratory experiments cited by JØRGENSEN (1990), the clearance rates we found are low for mussels ( $\left.2.5 \mathrm{vs} .7 .5 \mathrm{I} \mathrm{h}^{-1}\right)$. This difference may be explained by the longer period of observation (one tidal cycle) in the benthic ecosystem tunnels for which a mean clearance rate was calculated. The activity of the animals will not have been at its maximum during the whole tidal cycle. Moreover, high seston concentrations have been shown to reduce clearance rates of mussels and cockles (PRINS et al., 1991). Compared to observations on different populations of mussels (BAYNE, 1993) the rates presented in Table 3, lie within a normal range.

Although high seston loads in the water column do not appear ideal for growth, the relatively good quality of the food (indicated by the $\mathrm{C} / \mathrm{N}$ ratio) may contribute largely to the carrying capacity of the Bay of Marennes-Oléron for the cultivation of bivalves.

\section{ACKNOWLEDGEMENTS}

We would like to thank all Dutch colleagues who participated in the field work in France as well as the colleagues from IFREMER (La Tremblade) for their kind cooperation. Our thanks are also due to the Meetdienst Vlissingen of Rijkswaterstaat for providing current measuring equipment. The chemical analyses were carried out by $W$. Schreurs and staff of the National Institute for Coastal and Marine Management/RIKZ, Middelburg. This research is part of the EC-TROPHEE-project (FAR-contract no. AQ-2500). The first author worked for the Netherlands Institute of Ecology under contract with the National Institute for Coastal and Marine Management/RIKZ.

\section{REFERENCES}

BACHER, C., 1989. Capacité trophique du bassin de Marennes-Oléron: couplage d' un modèle de transport particulaire et d' un modèle de croissance de I huittre Crassostrea gigas. Aquat. Living Res., 48: 199-214.

BAYNE, B.L., 1993. Feeding-physiology of bivalves: time-dependence and compensation for changes in food available. In: R.F. Dame, Ed., Bivalve filter feeders in estuarine and coastal ecosystem processes. Springer Verlag, Berlin, p. 1-24.

BAYNE, B.L. and R.C. NEWELL, 1983. Physiological energetics of marine molluscs. In: K.M. Wilbur and A.S. Saleuddin, Eds., The Molluscs, Vol. 4. Academic Press, New York, p. 407-515

DAME, R.F. and N. DANKERS, 1988. Uptake and release of materials by a Wadden Sea mussel bed. J. exp. mar. Biol. Ecol., 118: 207-216 DAME, R.F., R. ZINGMARK and E. HASKIN, 1984. Oyster reefs as processors of estuarine materials. J. exp. mar. Biol. Ecol., 83: 239-247.

DAME, R., N. DANKERS, T. PRINS, H. JONGSMA and A. SMAAL, 1991. The influence of mussel beds on nutrients in the Western Wadden Sea and Eastern Scheldt estuaries. Estuaries, 14: 130-138.

DESLOUS-PAOLI, J.M. and M. HÉRAL, 1984. Transferts energétiques entre l'huître Crassostrea gigas de 1 an et la nourriture potentielle disponible dans l'eau d'un bassin ostréicole. Haliotis, 14: 79-90.

DESLOUS-PAOLI, J.M., M. HÉRAL, P. GOULLETQUER, W. BOROMTHANARAT, D. RAZET, J. GARNIER, J. PROU and L. BARILLÉ, 1987. Evolution saisonnière de la filtration de bivalves intertidaux dans les conditions naturelles. Océanis, 13: 575-579

TESLOUS-PAOLI, J.M., A.M. LANNOU, P. GEAIRON, S. BOUGRIER, O. RAILLARD and M. HÉRAL, 1992. Effects of the feeding behaviour of Crassostrea gigas (bivalve molluscs) on biosedimentation of natural particulate matter. Hydrobiologia, 231: 85-91.

FENCHEL, T. and B.B. JØRGENSEN, 1976. Detritus food chains of aquatic ecosystems and the role of bacteria. Adv. Microb. Ecol., 1: 1-49.

FIALA-MEDIONI, A. and M. COPELLO, 1984. Relation trophique entre l' huitre et le milieu: influence de la concentration et de la taille des particules. IFREMER, Actes et Colloques, 1: 63-74.

HÉRAL, M. D. RAZET, J.-M. DESLOUS-PAOLI, J.-P. BERTHOMÉ and J. GARNIER, 1983. Caractéristiques saisonnières de I' hydrobiologie du complexe estuarien de Marennes-Oléron (France). Rev. Trav. Inst. Pêches maritim., 42: 97-119.

JONES, H.D., O.G. RICHARDS and T.A. SOUTHERN, 1992. Gill dimensions, water pumping rate and body size in the mussel Mytilus edulis L. J. exp. mar. Ecol. Biol., 155: 213-237.

JØRGENSON, C.B., 1990. Bivalve filter feeding: hydrodynamics, bioenergetics, physiology and ecology. Olsen and Olsen, Fredensborg, p. 86

KAUTSKY, N. and S. EVANS, 1987. Role of biodeposition by Mytilus edulis in the circulation of matter and nutrients in a Baltic coastal ecosystem. Mar. Ecol. Progr. Ser., 38: 201-212.

KIøRBOE, T. and F. MøHLENBERG, 1981. Particle selection in suspension feeding bivalves. Mar. Ecol. Progr. Ser., 5: 291-296.

NEWELL, R.I.E. and S.J. JORDAN, 1983. Preferential ingestion of organic material by the American oyster Crassostrea virginica. Mar. Ecol. Progr. Ser., 13: 47-53.

PRESTON, M.R. and P. PRODDUTURU, 1992. Tidal variations of particulate carbohydrates in the Mersey Estuary. Estuar. Coast. Shelf Sci, 34: $37-48$.

PRINS, T.C. and A.C. SMAAL, 1990. Benthic-pelagic coupling: the release of inorganic nutrients by an intertidal bed of Mytilus edulis. In: M. Barnes and R.N. Gibson, Eds., Trophic relationships in the marine environment. Aberdeen University Press, Aberdeen, p. 89-103. 
PRINS, T.C. and A.C. SMAAL, 1994. The role of the blue mussel Mytilus edulis in the cycling of nutrients in the Oosterschelde Estuary (The Netherlands). In: P.H. Nienhuis and A.C. Smaal, Eds., The Oosterschelde Estuary (The Netherlands): case-study of a changing ecosystem. Kluwer Academic Publ., Dordrecht-Boston, p. 413-429.

PRINS, T.C., A.C. SMAAL and A.J. POUWER, 1991. Selective ingestion of phytoplankton by the bivalves Mytilus edulis L. and Cerastoderma edule (L.). Hydrobiol. Bull., 25: 93-100.

PROU, J., 1991. Evolution temporelle de la composition de la colonne d' eau pendant un cycle vives eaux - mortes eaux. Mémoire IFREMER Direction des Ressources Vivantes, p. 1-39.

RAZET, D., M. HÉRAL, J. PROU, J. LEGRAND and J.M. SORNIN, 1990. Variations des productions de biodepôts (tèces et pseudofèces) de I huitre Crassostrea gigas dans un estuaire macrotidal: Baie de Marennes-0léron. Haliotis, 10: 143-161.

RIISGÅRD, H.U., 1988. Efficiency of particle retention and filtration rate in 6 species of Northeast American bivalves. Mar. Ecol. Progr. Ser. 45: $217-223$

SMAAL, A.C. and T.C.PRINS, 1993. The uptake of organic matter and the release of inorganic nutrients by bivalve suspension feeder beds In: R.F. Dame, Ed., Bivalve filter feeders in estuarine and coastal ecosystem processes. Springer Verlag, Berlin, p. 271-298

SMAAL, A.C., J.H.G. VERHAGEN, J. COOSEN and H.A. HAAS, 1986. Interactions between seston quantity and quality and benthic suspension feeders in the Oosterschelde, The Netherlands. Ophelia, 26: 385-399.

SORNIN, J.M., M. FEUILLET, M. HÉRAL, and J.M. DESLOUS-PAOLI, 1983. Effet des biodépôts de I huitre Crassostrea gigas (Thunberg) sur I' accumulation de matières organiques dans les parcs du bassin de Marennes-0léron. J. molf. Stud., suppl. 12A: 185-197.

SORNIN, J.M., M. FEUILLET, M. HÉRAL, and J.C. FARDEAU, 1986. Influence des cultures d' huîtres Crassostrea gigas sur te cycle du phosphore en zone intertidale: rôle de la biodéposition. Oceanol. Acta, 9: 313-322.

ZURBURG, W., A.C. SMAAL, M. HÉRAL and N. DANKERS, 1994. In situ estimations of uptake and release of material by oysters in the Bay of Marennes-Oléron (France). Proc. ECSA/ERF Plymouth 1992. Olsen and Olsen, in press

\section{Addresses of the authors:}

1 Netherlands Institute of Ecology, Centre for Estuarine and Coastal Ecology, Vierstraat 28, 4401 EA Yerseke, The Netherlands.

2 Ministry of Transport, Public Works and Water Management, National Institute for Coastal and Marine Management/RIKZ, P.0.Box 8039, 4330 EA Middelburg, The Netherlands.

3 LABEIM-IFREMER, P.0.Box 133, 17390 La Tremblade, France

4 Institute for Forestry and Nature Research, P.O.Box 167, 1790 AD Den Burg, Texel, The Netherlands. 